\title{
Optimization of Calcium Chloride for Efficient In Vitro Regeneration in Cuminum cyminum L: A Significant Seed Spice
}

\author{
[Smita Purohit]
}

\begin{abstract}
Protecting our environment, while stabilizing the population and adequately feeding the people who will share the Earth in the next generation, is the largest challenge facing human kind today. The preservation of biodiversity can be accomplished only as part of an overall strategy to promote global stability. India is one of the richest countries in the world in terms of biodiversity. It is known worldwide for its rich repository of spices and thus popularly known as the "land of spices". Among various spices, seed spices play a major role in Indian history and commerce as they are cultivated in India since ancient times; also India enjoys the position of being the largest producer, consumer and exporter of seed spices in the world. Cuminum cyminum $\mathbf{L}$. is an important seed spice belonging to family Apiaceae. Production of cumin is limited due to several biotic stresses of which wilt diseases are the most serious. Efforts to improve cumin are limited due to the unavailability of broad genetic diversity. Therefore, the present study deals with in vitro tissue culture studies in Cuminum cyminum L.var. RZ 19 and to study the effect of calcium chloride on induction and proliferation of shoot buds from cotyledonary node explants Shoot buds were induced on medium supplemented with $0.5 \mathrm{Kn}$ $\mathrm{mg} / 1$. Proliferation of shoot buds was obtained on MS medium containing $0.5 \mathrm{Kn} \mathrm{mg/1}$. Both shoot induction and proliferation media were supplemented with different levels of $\mathrm{CaCl}_{2}\left(\mathrm{O}_{-}\right.$ 14.95mM). The levels of $\mathrm{CaCl}_{2}$ in the induction as well as proliferation medium highly influenced the shoot regeneration. Highest number of shoot buds per explant was obtained when the concentration of $\mathrm{CaCl}_{2}$ was increased 2 times the normal MS level. Shoot buds formation frequency i.e., the number of shoots formed per explant was increased 2 fold as compared to those formed on control cultures. Shoots upto $2 \mathrm{~cm}$ or more in length were excised and inoculated on rooting medium i.e., MS medium supplemented with $0.5 \mathrm{mg} / \mathrm{l}$ IBA. Rooted plantlets were transferred to field conditions. Peroxidise enzyme activity and the chlorophyll content of the shoots regenerated on calcium supplemented media was also studied.
\end{abstract}

Keywords- Cumin, Calcium, Regeneration, peroxidase, proliferation.

\section{Introduction}

Protecting our environment, while stabilizing the population and adequately feeding the people who will share the Earth in the next generation, is the largest challenge facing human kind today. The preservation of biodiversity can be

Smita Purohit

The IIS University, Jaipur

India accomplished only as part of an overall strategy to promote global stability. This would necessarily involve social equity issues, improved agriculture and forestry practices. Biotechnology applications to increase crop productivity in ways that will lower costs, improve quality and abundance, and provide for protection of the environment are critically needed. Biotechnology offers new opportunities for significantly increasing the productivity of agriculture and decreasing the environmental damage of agricultural practices. The products of biotechnology, however, are much more predictable and controllable than existing species that are introduced into new habitats. Improved crops developed by biotechnology retain the same original characteristics as the original crop with one or two specific modifications that can readily be observed for changes in adaptive, competitive properties before release to the environment. Advances in plant biotechnology provide new options for collection, multiplication and short- to long-term conservation of plant biodiversity.

India is one of the richest countries in the world in terms of biodiversity. It is known worldwide for its rich repository of spices and thus popularly known as the "land of spices". Among various spices, seed spices constitute a major role in Indian history and commerce as they are cultivated in India since ancient times; also India enjoys the position of being the largest producer, consumer and exporter of seed spices in the world. The country is bestowed with immensely rich land races and diversity in seed spices crops. Cuminum cyminum L. is an important seed spice belonging to family Apiaceae. It is cultivated extensively in Rajasthan and Gujarat where it is grown as a Rabi crop. Because of its low water requirements cumin is cultivated in drought-affected areas where most of the other crop plants cannot be grown economically. However, production of cumin is limited due to several biotic stresses of which wilt diseases are the most serious [1,2]. The conventional breeding in cumin is very difficult, slow, laborious and time consuming [3]. In addition, potential genetic variability for root wilt resistance is also limited by conventional breeding. Therefore, we have to look forward for the new technologies that can be explored and applied to enhance the production. Conventional breeding techniques have been of immense value for cumin genetic improvement but utilize huge amounts of seeds, which results in the wastage of the crop significantly. Moreover, low seed-set, which is due to the presence of only male flowers, underdeveloped flowers and lack of proper pollination and fertilization [4], is also a major constraint to propagation of agronomic traits and for commercial seed production. Biotechnological techniques involving plant tissue culture and recombinant DNA technologies could be influential supplementary tools to 
accelerate and achieve this objective. Therefore, in vitro tissue culture followed by gene transfer could be an easy, efficient and economic means for obtaining large number of diseasefree, uniform and true-to-type plants within a short span of time. Inorganic macronutrient and micronutrient levels used in most plant tissue culture media are based on levels established by Murashige and Skoog [5] for tobacco tissue culture. However, many plant species and varieties do not respond to classical approach, demonstrating that alterations in hormonal ratios cannot be the sole mechanism controlling in vitro developmental processes[6]. The present investigation was undertaken to see the effect of different levels of calcium chloride on regeneration of Cuminum cyminum.

Tissue culture techniques circumvents many constraints related to plant cultivation and have led to new opportunities of crop improvement since responses are well defined under control conditions. Organogenesis in vitro is a stress-related and energy-consuming process which is accompanied by intensification of catabolic and anabolic reactions [7]. It is well established that in vitro cultures can induce oxidative stress [8] which consequently makes the defensive mechanism of tissue cultured plants more efficient. Hence, the present work is an attempt to study the activities of antioxidant enzymes (peroxidase) in in vitro plants of cumin.

\section{Materials and methods}

\section{A. Establishment of aseptic seedlings and explant preparation}

Seeds of Cuminum cyminum L. var. RZ 19 were procured from NRCSS, Ajmer. The seeds were rinsed with 20\% (v/v) Extran (Merck, India) followed by 3-4 washings with sterile distilled water. These were then surface-sterilized with $0.1 \%$ $\mathrm{HgCl}_{2}$ aqueous solution for $3 \mathrm{~min}$ and rinsed with three changes of sterile distilled water. MS medium with $3 \%(\mathrm{w} / \mathrm{v})$ sucrose and solidified with $0.8 \%(\mathrm{w} / \mathrm{v})$ agar (Qualigens, bacteriological grade), $\mathrm{pH}$ adjusted to 5.8 before autoclaving at $121^{\circ} \mathrm{C}$ and $1.2-1.3 \mathrm{~kg} / \mathrm{cm}^{2}$ pressure for $20 \mathrm{~min}$ was prepared for germination of seedlings. Five seeds were kept in a single flask ( $100 \mathrm{ml}$ 'Erlenmeyer' with $40 \mathrm{ml}$ medium in each). All the cultures were incubated in growth chamber at a temperature of $26^{\circ} \mathrm{C} \pm 11^{\circ} \mathrm{C}$ and $16 \mathrm{~h}$ photoperiod and light intensity of $25 \mu \mathrm{mol} / \mathrm{m}^{2} / \mathrm{s}$ provided by white fluorescent tubes. Cotyledons were excised aseptically from 8-10 day old aseptically grown seedlings and the remaining cotyledonary node was used as an explant.

\section{B. Culture media}

The cotyledonary node explants were inoculated on the MS medium supplemented with $0.5 \mathrm{mg} / \mathrm{l} \mathrm{Kn}$ and sucrose $3 \%$ ( $\mathrm{w} / \mathrm{v})$. This was considered to be control induction medium having $2.99 * \mathrm{mM}$ of $\mathrm{CaCl}_{2}$ already present as a macronutrient in MS basal medium .The levels of calcium chloride $(0,0.74$, $1.49,2.99 *, 5.98,8.97,11.96,14.95 \mathrm{mM})$ were varied as 0 , 0.74 (one fourth), 1.49 (half), 2.99 (control, having normal calcium concentration in MS basal medium), 5.98, 8.97, $11.96,14.95 \mathrm{mM}$. Five flasks (100 ml 'Erlenmeyer' with 40 $\mathrm{ml}$ medium in each) were prepared for each treatment having three explants per flask. Visual observations were made for 5 weeks. Percentage response was calculated by dividing the total number of responding explants by total number of explants inoculated. Shoots buds induced from the explant were excised after 4 weeks and subcultured on normal proliferation medium PM 1(MS medium supplemented with $0.5 \mathrm{mg} / \mathrm{l} \mathrm{Kn}$ and calcium chloride $2.99 \mathrm{mM}$ as present in normal MS medium) and on modified proliferation medium PM 2 (MS medium supplemented with $0.5 \mathrm{mg} / \mathrm{l} \mathrm{Kn}$ and varied levels of calcium chloride: $0,0.74,1.49,2.99^{*}, 5.98,8.97$, $11.96,14.95 \mathrm{mM})$. Weekly observations were recorded for 5 weeks.

Shoot induction capability was observed taking into account the number and length of shoots per explant. Physiological characterization such as estimation of pigment concentration was determined in 4 weeks old culture and peroxidise enzyme activity was determined in 3 weeks and 5 weeks old cultures.

\section{Extraction for Peroxidase Enzyme}

One gram of fresh tissue (regenerated shoots) after three and five weeks of culture was ground by pre-chilled mortar and pestle with $0.05 \mathrm{M}$ potassium phosphate buffer ( $\mathrm{pH}$ 7.0). The homogenate was centrifuged for $20 \mathrm{~min}$ at $5000 \mathrm{rpm}$. After centrifugation, the pellet was discarded and supernatant was mixed with cold acetone to a final concentration of $70 \%$ and centrifuged at $5000 \mathrm{rpm}$ for $10 \mathrm{~min}$ and the supernatant was used for enzyme assay.

\section{Peroxidase assay:}

The peroxidase activity was assayed by Guaiacol- $\mathrm{H}_{2} \mathrm{O}_{2}$ method [9]. The reaction mixture was made by mixing $0.2 \mathrm{ml}$ enzyme extract, $1 \mathrm{ml}$ of $1 \%$ Guaioacol, $0.2 \mathrm{ml}$ of $50 \mathrm{mM}$ $\mathrm{H}_{2} \mathrm{O}_{2}$. Peroxidase activity was determined spectrophotometrically by monitoring the formation of tetraguaiacol at $470 \mathrm{~nm}$ after every 15 seconds. One unit of peroxidase activity corresponds to the levels of enzyme activity were expressed as moles of $\mathrm{H}_{2} \mathrm{O}_{2}$ destroyed/min/mg protein.

\section{CHLOROPHYLL (Chl)} [10].

Chlorophyll was estimated by the method demonstrated in

\section{Reagents}

$80 \%$ Acetone

Enzyme extract

\section{Extraction}

One gram regenerated shoots (4 weeks old) was chilled in deep freeze $\left(-20^{\circ} \mathrm{C}\right)$ and then homogenized in $80 \%$ acetone, centrifuged at $10,000 \mathrm{rpm}$ for $10 \mathrm{~min}$.

* Normal level in the MS medium 
Proc. of the Second Intl. Conf. on Advances in Bio-Informatics and Environmental Engineering - ICABEE 2015 Copyright (C) Institute of Research Engineers and Doctors, USA .All rights reserved.

ISBN: 978-1-63248-043-9 doi: 10.15224/ 978-1-63248-043-9-31

The supernatant obtained was used for chlorophyll estimation.

\section{Estimation}

The absorbance of the supernatant was read at 645 $\mathrm{nm}$ and $665 \mathrm{~nm}$ against $80 \%$ acetone solvent [10]. The amount of chlorophyll was calculated according to the following equation and the total amount of expressed as mg chlorophyll $\mathrm{g}$ fresh weight ${ }^{-1}$.

$$
\begin{aligned}
& \text { Chl a }= \\
& 12.7\left(A_{663}\right)-2.69\left(A_{645}\right) \times \frac{v}{1000 \times w}
\end{aligned}
$$

Chl b =

$$
22.9\left(A_{645}\right)-4.68\left(A_{663}\right) \times \frac{v}{1000 \times w}
$$$$
\text { Total Chl }=\quad \mathrm{Chl} \mathrm{a}+\mathrm{Chl} \mathrm{b}
$$

Where,

$$
\begin{array}{lll}
\mathrm{A} & = & \text { absorbance at specific wavelength } \\
\mathrm{W} & = & \text { weight of tissue taken } \\
\mathrm{V} & = & \text { volume taken for Chl estimation }
\end{array}
$$

\section{Rooting and Acclimatization}

Shoots upto $2 \mathrm{~cm}$ and more in length were excised and transferred on to rooting medium consisting of full strength MS medium supplemented with $0.5 \mathrm{mg} / 1$ IBA. Plantlets with well-developed shoot and root systems were carefully taken out and washed with tap water to remove agar. These plantlets were then transferred to earthen pots containing garden soil and organic manure $(1: 1)$. Humidity was maintained initially by covering the pots with polythene bags. The experiment was repeated three times.

\section{Results \& Discussion}

The entire experiment was conducted in two phases. In the first phase of experiment a standard protocol was established to determine the optimized hormonal combination for regeneration from the cotyledonary node explants. It was found that $\mathrm{Kn}(0.5 \mathrm{mg} / \mathrm{l})$ promoted shoot bud induction (Fig. 1 ). The shoot buds formed were sectored in small clumps and sub-cultured on proliferation medium containing $\mathrm{Kn}(0.5$ $\mathrm{mg} / \mathrm{l})$.

In the second stage, effect of modified levels of calcium in the proposed medium was studied. Cotyledonary node explants cultured on shoot bud induction medium became swollen and multiple shoot primordia emerged from the explants after 2 weeks. Shoots buds formed were normal and healthy. Calcium levels highly influenced the frequency of shoot buds (Table1). Induction of primary shoots was seen in the absence of $\mathrm{CaCl}_{2}$ in the induction medium but they were less in number and did not proliferate on subculture. On

\begin{tabular}{|c|c|c|c|}
\hline $\begin{array}{c}\mathrm{CaCl}_{2}(\mathrm{mM}) \\
\text { in primary } \\
\text { culture }\end{array}$ & $\begin{array}{l}\text { No. of shoot } \\
\text { buds / } \\
\text { explant } \\
\text { Mean } \pm \text { S.D. }\end{array}$ & $\begin{array}{c}\mathrm{CaCl}_{2}(\mathrm{mM}) \\
\text { in second } \\
\text { stage } \\
\text { subculture } \\
\end{array}$ & $\begin{array}{l}\text { No. of shoot } \\
\text { buds/explant } \\
\text { Mean } \pm \text { S.D. }\end{array}$ \\
\hline \multirow[t]{2}{*}{0} & \multirow{2}{*}{$2.2 \pm 0.4$} & 0 & 0 \\
\hline & & $2.99^{\mathrm{a}}$ & 0 \\
\hline \multirow[t]{2}{*}{0.74} & \multirow[t]{2}{*}{$2.8 \pm 0.8$} & 0.74 & $4.2 \pm 1.1$ \\
\hline & & $2.99^{\mathrm{a}}$ & $5.4 \pm 1.5$ \\
\hline \multirow[t]{2}{*}{1.49} & \multirow[t]{2}{*}{$4.2 \pm 1.1$} & 1.49 & $9.6 \pm 1.3$ \\
\hline & & $2.99^{\mathrm{a}}$ & $11.8 \pm 1.3$ \\
\hline $2.99^{\mathrm{a}}$ & $4.6 \pm 0.4$ & $2.99^{\mathrm{a}}$ & $13.6 \pm 1.9$ \\
\hline \multirow[t]{2}{*}{5.98} & \multirow[t]{2}{*}{$10.8 \pm 1.4$} & $2.99^{\mathrm{a}}$ & $27.8 \pm 1.6$ \\
\hline & & 5.98 & $48 \pm 3.5$ \\
\hline \multirow[t]{2}{*}{8.97} & \multirow[t]{2}{*}{$5 \pm 1$} & $2.99^{\mathrm{a}}$ & $12.8 \pm 1.7$ \\
\hline & & 8.97 & $12 \pm 0.7$ \\
\hline \multirow[t]{2}{*}{11.96} & \multirow[t]{2}{*}{$5.4 \pm 1.3$} & $2.99^{\mathrm{a}}$ & $11.8 \pm 1.1$ \\
\hline & & 11.96 & $9.6 \pm 1.3$ \\
\hline \multirow[t]{2}{*}{14.95} & \multirow[t]{2}{*}{$2.8 \pm 0.8$} & $2.99^{\mathrm{a}}$ & $9.1 \pm 2.1$ \\
\hline & & 14.95 & $3.2 \pm 0.8$ \\
\hline
\end{tabular}
control, each explant induced 4-5 normal shoot buds.
TABLE I. EFFECTS OF $\mathrm{CACL}_{2}$ ON SHOOT BUD FORMATION FROM COTYLEDONARY NODES OF $C$. CYMINUM CULTURED ON MS MEDIUM SUPPLEMENTED WITH KN $(0.5 \mathrm{MG} / \mathrm{L})$

Number of explants $=\mathbf{5 0}$

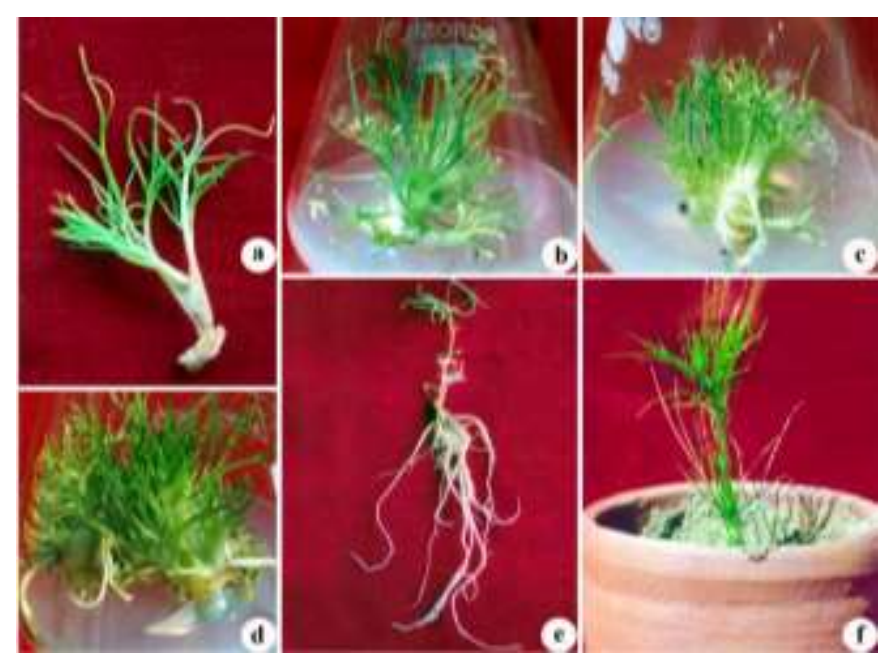

Figure 1. Shoot bud induction and proliferation from cotyledonary nodes of Cuminum cyminum L. cultured on MS medium supplemented with $\mathrm{Kn}(0.5$ $\mathrm{mg} / \mathrm{l})$ and various levels of $\mathrm{CaCl}_{2}$ (a). $2.99 \mathrm{mM} \mathrm{CaCl}_{2}$ (b). $5.98 \mathrm{mM} \mathrm{CaCl}_{2}$

(c). $2.99 \mathrm{mM} \mathrm{CaCl}_{2}$ (induced on similar medium) (d). $5.98 \mathrm{mM} \mathrm{CaCl}_{2}$ (induced on similar medium) (e).Rooting of regenerated shoots on MS + IBA $(0.5 \mathrm{mg} / \mathrm{l})(\mathrm{f})$. Field transferred plant 
There was a concommitant increase in number of shoot buds with increasing concentration of calcium till the level for mineral was optimized at $5.98 \mathrm{mM}$ which is 2 times higher than the MS level of $\mathrm{CaCl}_{2}$ (Fig. $1 \mathrm{~b}$ ). The number of shoots formed was almost double in number as compared to the control. Inhibitory effect on shoot bud formation was witnessed when the calcium levels were increased beyond $5.98 \mathrm{mM}$. Shoot buds formed on calcium supplemented medium were sub-cultured on proliferation medium (PM1 and PM2) (Table 1). Shoot buds induced on $5.98 \mathrm{mM} \mathrm{CaCl}_{2}$ in the induction medium when subcultured on PM1 $(2.99 \mathrm{mM}$ $\mathrm{CaCl}_{2}$ ) yielded an average of 27 shoots per explant and an average of 48 shoots per explant was produced on PM2 (5.98 $\mathrm{mM}$ ) with similar levels of $\mathrm{CaCl}_{2}$. Higher levels were not favourable for proliferation of shoot buds.

Increased calcium levels in the medium significantly favoured the induction and proliferation of shoots in Cuminum cyminum. Calcium is an essential plant nutrient [11] . Jansen et al. in [12] reported a 2-fold increase in the number of somatic embryos from Daucus carota suspension cultures due to an increase in calcium concentrations in medium. Similar response was seen in cytokinin induced shoot bud formation in Torenia stem segments [13]. According to [14] calcium plays a role in the control of embryogenesis while Capitani and Altamura [15] assumed that calcium ions are involved in the control of all types of meristem organization.

Peroxidase Activity: Significant variation in endogenous peroxidase activity was detected on different calcium supplemented media. There was an increase in POD activity with the increase in concentration of calcium in the medium. Maximum activity was observed on medium supplemented with $14.95 \mathrm{mM} \mathrm{CaCl}_{2}$ (Fig. 2). In vitro cultures are good model systems for studying

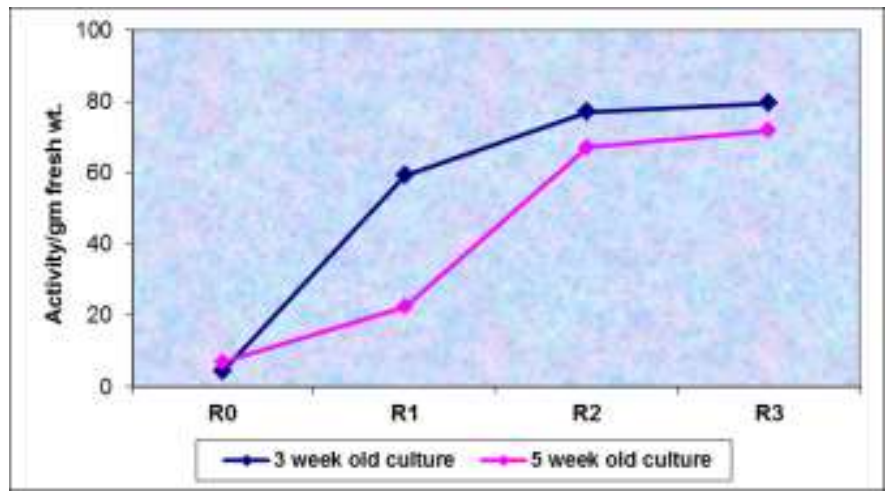

Figure 2. Peroxidase activity profile in shoots regenerated on different levels of $\mathrm{CaCl}_{2}$

oxidative stress and antioxidants that follow. The enhanced activities of enzyme indicate that the defense mechanism in the in vitro plants were active against oxidative stress. Shamsi et al. in [16] postulated that increase in the POD activity is a general response of higher plants to uptake toxic amounts of metals or minerals in order to overcome the oxidative stress faced by the plant cells.

Chlorophyll Content: The chlorophyll content in plants is often measured to assess the impact of the stress on plants.
The chlorophyll content of the shoots increased with the increase in the level of calcium chloride in the medium. The chlorophyll content of the shoot buds induced on calcium chloride supplemented medium increased up to $5.98 \mathrm{mMM}$ of calcium chloride. Further raising the levels (upto $14.95 \mathrm{mM}$ ) resulted in decrease in chlorophyll content of shoots (Fig. 3).

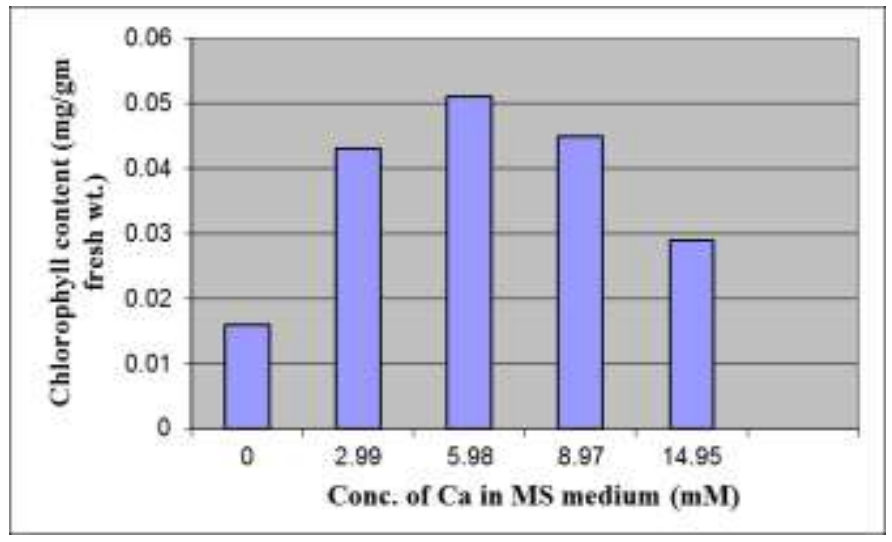

Figure 3. Chlorophyll content of shoots of C. cyminum regenerated on MS medium supplemented with PGRs and different levels of calcium

To summarize, in this study we have investigated the effect of various levels of calcium on in vitro shoot morphogenesis and $5.98 \mathrm{mM}$ of $\mathrm{CaCl}_{2}$ was found to be optimum for induction and subsequent proliferation of cumin. Incorporation of $\mathrm{CaCl}_{2}$ in the medium affected the peroxidise enzyme activity as well as the chlorophyll content in the regenerated shoots.

\section{References}

[1] Stuart, M.K., A.V. Barak and W.E. Burkholder, 1994. Immunological identification of Trogoderma granarium everts. J. Stored Prod. Res., 30: 9-16.

[2] Agrawal, S., 1996. Volatile oil constituents and wilt resistance in cumin (Cuminum cyminum L.). Curr. Sci., 71: 177-178.

[3] Hunault G, Desmarest P and Du Manoir J (1989) Foeniculum vulgare Miller: cell culture, regeneration and the production of anethole. In: Bajaj YPS (ed.) Biotechnology in Agriculture and Forestry 7: Medicinal and Aromatic Plants II Springer-Verlag, Berlin, Germany, pp 185-212.

[4] Sehgal CB (1978) Differentiation of shoot-buds and embryoids from inflorescence of Anethum graveolens in cultures. Phytomorphology 28: 291-297.

[5] Murashige T and Skoog F (1962) A revised medium for rapid growth and bioassays with tobacco tissue cultures. Physiol Plant 15: 473-497.

[6] Ramage CM and Williams RR (2003) Mineral uptake in tobacco leaf discs during different developmental stages of shoot organogenesis. Plant Cell Rep 21: 1047-1053

[7] Balen B, Tkalec M, Pavokovič D, Pevalek-Kozlina B, Krsnik-Raso M. Growth conditions in in vitro culture can induce oxidative stress in Mammillaria gracilis tissues. J Plant Growth Regul. 2009;28:36-45. doi: 10.1007/s00344-008-9072-5.

[8] Feher, A., T.P.Pasternak and D.Dudits.2003. Transition of somatic plant cells to an embryogenic state. Plant Cell Tiss. Org. Cult. 74: 201-228. improvement. Euphytica. 118: 153-166.

[9] Racusen and Foote, 1965). Racusen, D., Foote, M. (1965) Protein synthesis in dark-grown bean leaves, Can. J. Bot. 43(7): 817-824.

[10] Arnon (1949). Arnon, D. I. (1949) Copper enzymes in isolated chloroplasts. Polyphenoloxidase in Beta vulgaris, Plant Physiol. 24: 115 . 
Proc. of the Second Intl. Conf. on Advances in Bio-Informatics and Environmental Engineering - ICABEE 2015

Copyright $\odot$ Institute of Research Engineers and Doctors, USA .All rights reserved.

ISBN: 978-1-63248-043-9 doi: 10.15224/ 978-1-63248-043-9-31

[11] White P and Broadley MR (2003) Calcium in plants. Ann Bot 92: $487-$ 511.

[12] Jansen MAK, Booij H, Schel JHN and deVries SC (1990) Calcium increases the yield of somatic embryos in carrot embryogenic suspension cultures. Plant Cell Rep 9: 221-223.

[13] Tanimoto S, Harada H (1986) Involvement of calcium in adventitious bud initiation in Torenia stem segments. Plant Cell Physiol 27: 1-10.

[14] Timmers ACJ, Reiss HD, Bohsung J, Traxel K and Schel JHN (1996) Localization of calcium during somatic embryogenesis of carrot (Daucus carota L.). Protoplasma 190: 107-118.

[15] Capitani F and Altamura MM (2004) Exogenous calcium enhances the formation of vegetative buds, flowers and roots in tobacco pith explants cultured in the absence of exogenous hormones. Plant Cell Tiss Org Cult 77: 1-10.

[16] Shamsi, I. H., Wei, K., Zhang, G. P., Jilani, G. H., Hassan, M. J. (2008) Interactive effects of cadmium and aluminium on growth and antioxidative enzymes in soybean, Biol. Plant.. 52(1): 165-169.

\section{About Author (s):}

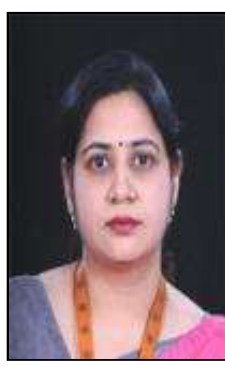

Dr. Smita Purohit, M.Sc (2000), gold medalist, Ph.D (2001) from the University of Rajasthan, Jaipur under the supervision of Prof. S.L.Kothari. Presently she's working as a Senior Assistant Professor in The IIS University, Jaipur. Her current research interest is inplant biotechnology in improving seed spices and ornamental plants through the use of advanced biotechnological approaches including plant tissue culture and micropropagation. 